\title{
PLASMA CHOLESTEROL SATURATION IN PATIENTS WITH \\ HYPERTENSION. WITH A NOTE ON PREPARATION OF \\ GLASS FILTERS FOR MICRO-FILTRATION OF \\ CHOLESTEROL DIGITONIDE
}

\author{
By RAYMOND F. HOLDEN, JR. \\ (From the Hospital of the Rockefeller Institute for Medical Research, New York City)
}

(Received for publication April 15, 1937)

Various authors during the past 25 years have attributed to hypercholesterolemia a rôle in initiating the arterial lesions of essential hypertension. The basis of this theory has been disproved by several recent papers $(1,2,3)$, which have shown that plasma cholesterol, both free and esterified, is entirely normal in essential hypertension.

However, Alvarez and Neuschlosz (4) have presented a series of experiments which indicated that the serum of patients with arterial hypertension may be supersaturated with cholesterol, even though the concentration does not exceed normal limits. Medvei (5) was unable to confirm Alvarez and Neuschlosz, and the disagreement in experimental results has remained unsettled. We have accordingly performed a series of saturation experiments on plasma from subjects with and without hypertension.

\section{EXPERIMENTAL}

Plasma was used in preference to serum because it approximates closer to the true circulat-

TABLE I

Plasma cholesterol values before and after saturation with free cholesterol

\begin{tabular}{|c|c|c|c|c|c|c|c|c|c|c|}
\hline \multirow{3}{*}{ Patient } & \multirow{3}{*}{$\underset{\substack{\text { Hospi- } \\
\text { tal } \\
\text { ber }}}{-}$} & \multirow{3}{*}{ Age } & \multirow{3}{*}{ Diagnosis } & \multirow{3}{*}{$\begin{array}{c}\text { Blood } \\
\text { pressure }\end{array}$} & \multicolumn{4}{|c|}{ Plasma cholesterol } & \multirow{3}{*}{$\begin{array}{c}\text { Total } \\
\text { lipid } \\
\text { carbon }\end{array}$} & \multirow{3}{*}{$\begin{array}{c}\begin{array}{c}\text { Free } \\
\text { cholesterol }\end{array} \\
\begin{array}{c}\text { Degree of } \\
\text { saturation }\end{array}\end{array}$} \\
\hline & & & & & \multicolumn{2}{|c|}{ Free } & \multicolumn{2}{|c|}{ Total } & & \\
\hline & & & & & $\begin{array}{c}\text { Before } \\
\text { satu- } \\
\text { ration }\end{array}$ & $\begin{array}{l}\text { After } \\
\text { satu- } \\
\text { ration }\end{array}$ & $\begin{array}{c}\text { Before } \\
\text { satu- } \\
\text { ration }\end{array}$ & $\begin{array}{l}\text { After } \\
\text { satu- } \\
\text { ration }\end{array}$ & & \\
\hline \multicolumn{11}{|c|}{ CONTROL GROUP } \\
\hline $\begin{array}{l}\text { R. H.... } \\
\text { B. M. } \ldots \\
\text { G. Z. } \ldots \\
\text { H. Y. } \ldots \\
\text { M. S.... }\end{array}$ & $\begin{array}{l}9696 \\
9693 \\
9723\end{array}$ & \begin{tabular}{|c|} 
years \\
25 \\
31 \\
49 \\
40 \\
48
\end{tabular} & $\begin{array}{l}\text { Healthy } \\
\text { Healthy } \\
\text { Pneumonia-convalescent } \\
\text { Pneumonia-convalescent } \\
\text { Pneumonia-convalescent }\end{array}$ & \begin{tabular}{l|}
$m m . H g$ \\
$122 / 82$ \\
$118 / 88$ \\
$118 / 80$ \\
$110 / 70$
\end{tabular} & \begin{tabular}{|c|} 
mgm. \\
per cent \\
49 \\
62 \\
56 \\
59 \\
50
\end{tabular} & \begin{tabular}{|c|} 
mgm. \\
per cent \\
53 \\
66 \\
57 \\
59 \\
50
\end{tabular} & \begin{tabular}{|c|} 
mgm. \\
per cent \\
208 \\
220 \\
176 \\
194 \\
196
\end{tabular} & \begin{tabular}{|c|} 
mgm. \\
per cent \\
202 \\
233 \\
173 \\
196 \\
203
\end{tabular} & $|\underset{\text { per cent }}{\text { mgm. }}|$ & $\begin{array}{r}\text { per cent } \\
94 \\
98 \\
100 \\
100\end{array}$ \\
\hline \multicolumn{11}{|c|}{ HYPERTENSIVE GROUP } \\
\hline $\begin{array}{l}\text { L. S..... } \\
\text { W. A..... } \\
\text { R. J..... } \\
\text { A. R.... } \\
\text { T. G.... } \\
\text { P. M.... } \\
\text { J. C..... }\end{array}$ & \begin{tabular}{|l|}
9490 \\
9399 \\
9452 \\
9506 \\
9543 \\
9480 \\
9839
\end{tabular} & $\begin{array}{l}53 \\
35 \\
26 \\
46 \\
37 \\
24 \\
40\end{array}$ & $\begin{array}{l}\text { Benign hypertension } \\
\text { Benign hypertension } \\
\text { Malignant hypertension } \\
\text { Malignant hypertension } \\
\text { Malignant hypertension } \\
\text { Malignant hypertension } \\
\text { Malignant hypertension }\end{array}$ & $\begin{array}{l}184 / 112 \\
117 / 112 \\
174 / 118 \\
260 / 160 \\
210 / 122 \\
174 / 108 \\
269 / 146\end{array}$ & $\begin{array}{l}45 \\
79 \\
56 \\
60 \\
48 \\
90\end{array}$ & $\begin{array}{l}41 \\
80 \\
54 \\
64 \\
45 \\
90\end{array}$ & $\begin{array}{l}158 \\
269 \\
251 \\
175 \\
200 \\
153 \\
289\end{array}$ & $\begin{array}{l}162 \\
266 \\
259 \\
169 \\
209 \\
149 \\
291\end{array}$ & 742 & $\begin{array}{r}110 \\
99 \\
99 \\
104 \\
94 \\
107 \\
100\end{array}$ \\
\hline \multicolumn{11}{|c|}{ NEPHRITIC GROUP } \\
\hline $\begin{array}{l}\text { L. C..... } \\
\text { F. B.... } \\
\text { A. C. } \ldots \\
\text { G. P.... } \\
\text { A. C.... }\end{array}$ & $\begin{array}{l}9465 \\
9525 \\
(4 \text { hour } \\
. \mid \begin{array}{l}8658 \\
8740 \\
9266\end{array}\end{array}$ & $\begin{array}{l}24 \\
30 \\
\text { rs after } \\
22 \\
22 \\
30\end{array} \mid$ & $\begin{array}{l}\text { Chronic hemorrhagic Bright's disease } \\
\text { Chronic hemorrhagic Bright's disease } \\
100 \mathrm{cc} \text {. of olive oil by mouth) } \\
\text { Chronic hemorrhagic Bright's disease } \\
\text { Chronic hemorrhagic Bright's disease } \\
\text { Chronic hemorrhagic Bright's disease }\end{array}$ & $\begin{array}{l}118 / 86 \\
186 / 108 \\
240 / 116 \\
164 / 100 \\
124 / 74\end{array}$ & $\begin{array}{r}58 \\
110 \\
134 \\
42 \\
101 \\
152\end{array}$ & $\begin{array}{r}53 \\
111 \\
132 \\
42 \\
100 \\
154\end{array}$ & $\begin{array}{l}186 \\
264 \\
306 \\
133 \\
355 \\
432\end{array}$ & $\begin{array}{l}186 \\
270 \\
320 \\
145 \\
354 \\
433\end{array}$ & $\begin{array}{r}396 \\
765 \\
1110\end{array}$ & $\begin{array}{r}109 \\
99 \\
101 \\
100 \\
101 \\
99\end{array}$ \\
\hline
\end{tabular}


ing fluid. Heparin was chosen as anticoagulant in order to minimize changes in cell-plasma equilibria which might conceivably affect the state of plasma cholesterol; also to avoid the saponification of cholesterol esters by oxalate or citrate, pointed out by Shope (6). The experiments were carried out at $37^{\circ} \mathrm{C}$. in a further effort to approximate in vivo conditions.

To obtain plasma for each saturation experiment, 20 cc. of blood obtained by venipuncture were run into a $50 \mathrm{cc}$. pyrex flask containing about $10 \mathrm{mgm}$. of heparin. The blood was whirled in the flask to assure complete mixing of the heparin, poured into a heavy centrifuge tube, and centrifuged at 2500 r.p.m. for 45 minutes. After pipetting off the supernatant plasma, it was divided into two equal portions of about $5 \mathrm{cc}$. each in $30 \mathrm{cc}$. pyrex flasks. About $50 \mathrm{mgm}$. of cholesterol were added to the contents of one flask and thoroughly suspended by gentle shaking. Both flasks were then closed with rubber stoppers and placed in an incubator at $37^{\circ} \mathrm{C}$. for 6 hours. $^{1}$ At the end of this period, the sample of plasma without added cholesterol was filtered with gentle suction through a $4 \mathrm{~cm}$. Buchner funnel fitted with a close-fibered filter paper. The sample with added cholesterol was then filtered through the same paper, with care to discard the first 1 to $2 \mathrm{cc}$. of filtrate. Both filtrations were carried out in the warm room at $37^{\circ} \mathrm{C}$. Free and total cholesterol determinations were made in duplicate on each sample by the method of Kirk, Page, and Van Slyke (7), with minor modifications. In a few cases, total lipid carbon was determined by the method of the same authors. The results are shown in Table I.

\section{DISCUSSION}

It is apparent from Table I that no pronounced changes in cholesterol content of the plasma samples studied were brought about by saturation with added cholesterol. Both free and total cholesterol remained essentially the same. Such variations as did occur are not consistent in di-

1 Incubation for longer periods has no effect on the results obtained and, unless sterile precautions are taken throughout, is certain to result in contamination by bacterial growth. Mechanical agitation during the saturation period had no effect on the cholesterol content of plasma samples. rection and therefore are probably without real significance.

\section{SUM MARY}

No evidence of a relationship between blood pressure and plasma cholesterol saturation was found in a series of cases which included individuals with malignant hypertension, benign hypertension, and chronic hemorrhagic nephritis. The plasma was approximately saturated with regard to free cholesterol in all cases.

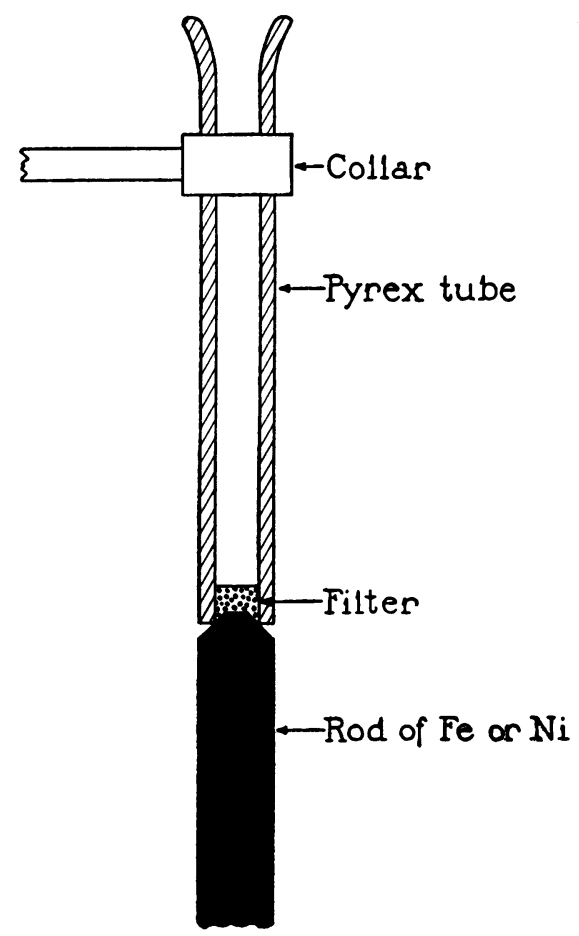

Fig. 1. Method for Sintering Glass Filters.

NOTE ON PREPARATION OF SINTERED GLASS FILTERS FOR MICRO-FILTRATION OF CHOLESTEROL DIGITONIDE

Kirk, Page and Van Slyke (7) used filter sticks with detachable tips for filtration and washing of the cholesterol digitonide precipitate. The filtering disk was of porous alundum. As the original supply of alundum in the laboratory was exhausted, it proved difficult to obtain more which would resist the chromic acid combustion fluid for many analyses. We have accordingly changed the porous disk from alundum to sintered pyrex glass. The filter sticks can be prepared with the sintered glass disks as follows.

Bits of broken pyrex laboratory ware are ground to a powder in a large mortar. This powder is shaken on a 100 -mesh screen and the screenings reserved, while the 
tailings are reground and rescreened until a sufficient stock of material is obtained. The screened powder is agitated with distilled water in a small beaker and the supernatant water carrying the finest particles is decanted after a 10 -second period, the process being repeated three or four times. The residual powder is then washed on to a filter paper and washed once with a saturated solution of sodium borate (borax). The paper and its contents are then dried over a steam bath. After breaking up the resultant cake into a powder again, it is ready for use.

The detachable lower end of a Kirk-Page-Van Slyke filter stick of pyrex glass is placed upright on a short iron or nickel rod as shown in Figure 1. Tubing of about $6 \mathrm{~mm}$. internal diameter and $2 \mathrm{~mm}$. wall thickness in lengths of about $8 \mathrm{~cm}$. is used. The end of the metal rod is beveled at an angle of $45^{\circ}$. The bevel results in the formation of a shoulder on the finished disk, a feature of some importance.

An amount of the powdered pyrex glass prepared as above is run into the upper end of the tube, so that the upper level is somewhat above that indicated in the diagram. The matrix is then packed and smoothed by gentle tamping with a blunt glass rod. After tamping the matrix, it should have a thickness of at least $3 \mathrm{~mm}$.

An air-gas blast is adjusted to deliver maximum heat intensity and brought to bear on the lower end of the tube and upper end of the metal rod, while slowly rotating about them. The upper end of the rod should reach a white heat, to insure a uniform face on the filter. The matrix will sinter at a bright red heat. The exact conditions of heating can be determined with a few trials.
If the matrix is insufficiently heated the particles in the center will not adhere to each other, while excessive heating will fuse the matrix into a solid mass. With a little practice, both of these exigencies may be avoided. The method is rapid, as the three operations of sintering a filter disk, fusing it into tubing and fire-polishing the end of the tubing are performed at one time. It is not adaptable for making filters larger than $1 \mathrm{~cm}$. in diameter.

\section{BIBLIOGRAPHY}

1. Page, I. H., Kirk, E., and Van Slyke, D. D., Plasma lipids in essential hypertension. J. Clin. Invest., 1936, 15, 109.

2. Landé, K. E., and Sperry, W. M., Human atherosclerosis in relation to the cholesterol content of the blood serum. Arch. Path., 1936, 22, 301.

3. Elliot, A. H., and Nuzum, F. R., Cholesterol content of whole blood in patients with arterial hypertension. Arch. Int. Med., 1936, 57, 63.

4. Alvarez, C., and Neuschlosz, S. M., Untersuchungen über das Blutcholesterin bei arteriellem Hochdruck. Klin. Wchnschr., 1931, 10, 244.

5. Medvei, C. V., Zur Frage des Blutcholesterins bei arteriellem Hochdruck. Klin. Wchnschr., 1932, 11, 414.

6. Shope, R. E., Differences in serum and plasma content of cholesterol ester. J. Biol. Chem., 1928, 80, 125.

7. Kirk, E., Page, I. H., and Van Slyke, D. D., Gasometric microdetermination of lipids in plasma, blood cells, and tissues. J. Biol. Chem., 1934, 106, 203. 